\title{
IMPACT OF LAND USE CHANGES ON THE GEOMORPHOLOGICAL PATTERN BETWEEN 1957-2018 WITHIN SARATA CATCHMENT, REPUBLIC OF MOLDOVA
}

DOI: https://doi.org/10.18509/AGB.2020.18

UDC: 502.52:504.61]:551.311(498)

\author{
Silvia Vacula, Lilian Niacşu \\ “Alexandru Ioan Cuza” University of Iaşi, Romania \\ corresponding author: silviana7@yahoo.com
}

submitted: 03.03 .2020

accepted: 17.05 .2020

published: 15.09 .2020

\begin{abstract}
Commonly, the land use pattern highlights the impact of the anthropic activities. Much more, mainly for the agricultural lands of the Republic of Moldova, this represents also a determining factor in land degradation through the manifestation of the geomorphological processes. Located in the southern part of the Moldavian Plateau (Republic of Moldova), our research area is typified by prevalence of soil erosion, sedimentation, gullies and landslides. Under these circumstances, our study aims to analyze the spatial and temporal evolution of land use pattern starting from the 1970s till now and to establish the impact of the geomorphological processes in the state of land degradation. From methodological point of view, our research stands on a comprehensive spatial data base which was created based on successive topographical maps (in scale 1:25,000), aerial photo maps (in scale 1:5,000) and consistent field observations. The overall results show that the present land use pattern of Sarata catchment (70600ha) is characterized by the prevalence of highly fragmented agricultural lands on $2 / 3$ from total area. In opposition, in the case of the period before 1990, the centralized communist policy favored the soil erosion control systems applied either on large arable plots or on widespread vineyards and orchards plantations. Much more, our results highlights that the land use dynamics was substantially influenced by land reforms (e.g. the land reform of 1991) that especially favored soil erosion, the most widespread process at the level of the entire research area. In conclusion, the comparative analysis reveals the irrational land use which is closely related to the decrease of soil \& land quality, the main natural resource of the entire country. Also, the need for large-scale (re)implementation of land improvement projects especially on arable lands is substantiated.
\end{abstract}

Keywords: irrational land use, land degradation, geomorphological processes, land improvement projects.

\section{INTRODUCTION}

Sarata catchment is located in the southern part of the Moldavian Plateau (Republic of Moldova), having the surface of $706 \mathrm{~km}^{2}$.The Sărata river springs from the bottom of the accumulation lake, located at the southern periphery of the village Sărata-Mereșeni (Hînceşti district). It opens in the Prut river at $187 \mathrm{~km}$ from the mouth, $1.5 \mathrm{~km}$ northwest of the village of Nicolaevca (Leova district). The length of the river is $59 \mathrm{~km}$. It borders in the northwest with the Lăpușnei Basin, northeast with the Cogâlnic Basin, south-east with the Ialpug Basin, south and southwest with the Prut River basin in which it opens. The main tributaries of the river are: on the right the Orac river $(22 \mathrm{~km})$, on the left the Sărăţica river $(15 \mathrm{~km})$. The Sărata River is part of the lower Prut River, and is among the last left tributaries that flow over it.

The climate is temperate continental with annual temperature of $9.5-10^{\circ} \mathrm{C}$ and mean annual precipitation of about 500-550 $\mathrm{mm}$. Implementation of soil and water conservation practices is a very important link to sustainable land use pattern [1], [2], [3]. During the communist period, the Sarata catchment was the subject of widespread land improvement projects [4], [9], [10]. After 1991, a varied complex of non- 
conservative land use actions became generalized. Thus, the land use changes, excessive fragmentation of arable land or deforestation have contributed to enhancement of land degradation
[10], [11] through geomorphological processes: soil erosion [5], gullies [6], [7] and landslides [8], sedimentation [5].

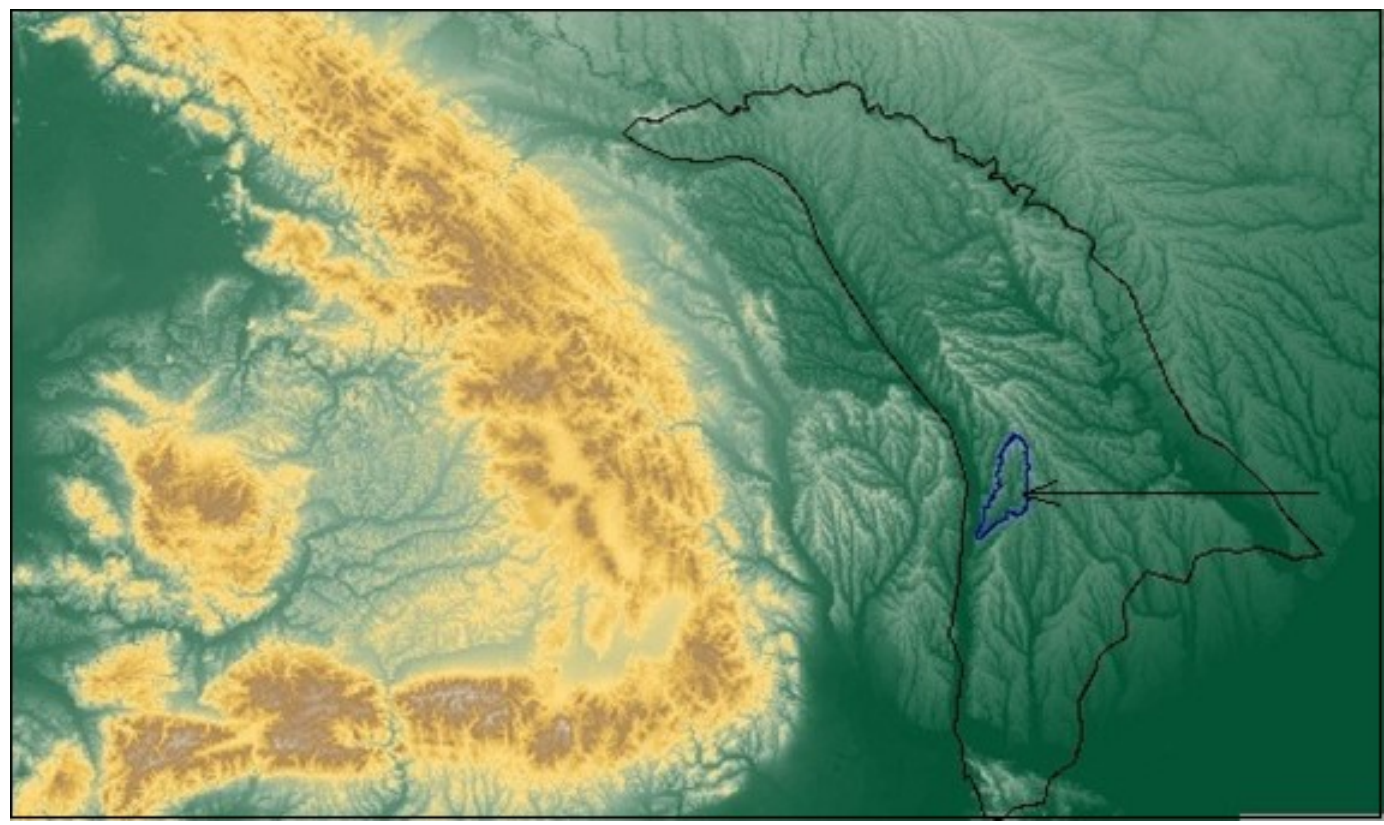

Figure 1. The geographic position of the catchment of the Sarata.

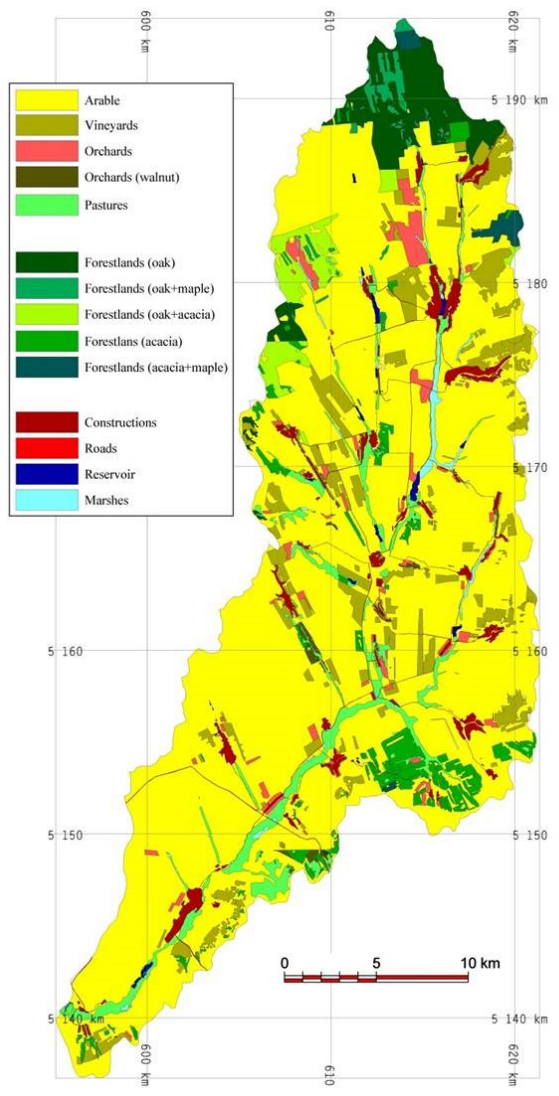

Figure 2. Land use within the Sarata catchment, southern part of the Republic of Moldova 1957-1970.

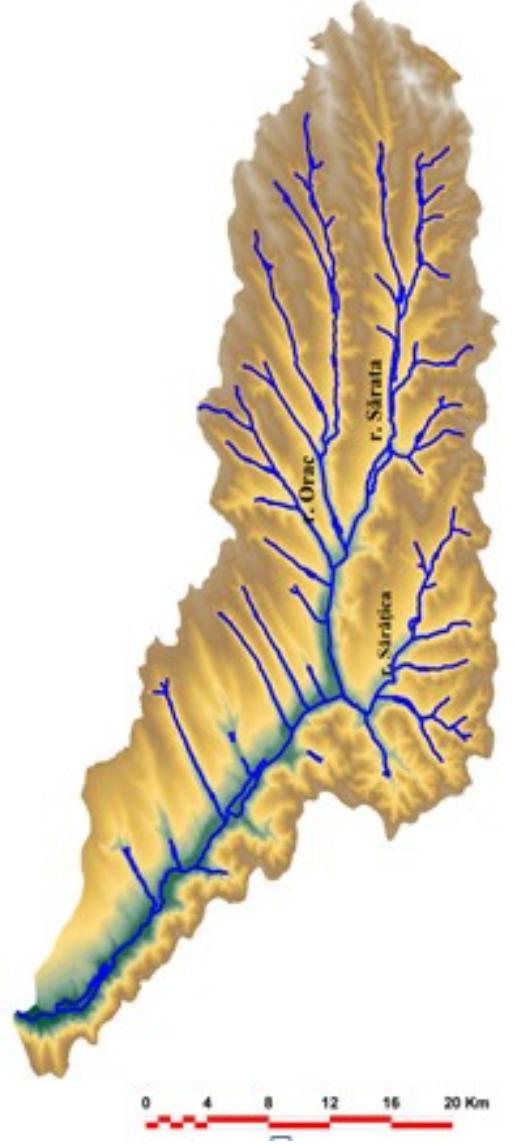

Figure 3. Sarata catchment 


\section{MATERIAL AND METHODS}

The research stands on a comprehensive spatial data base which was created based on successive topographical maps (in scale 1:25,000), aerial photo maps and consistent field observations. In order to obtain and process the land use map, the
TNT Mips software was used, the map being mapped from 1: 25000 and the polygons were created to estimate the surfaces of each category of agricultural use (fig.4-11).

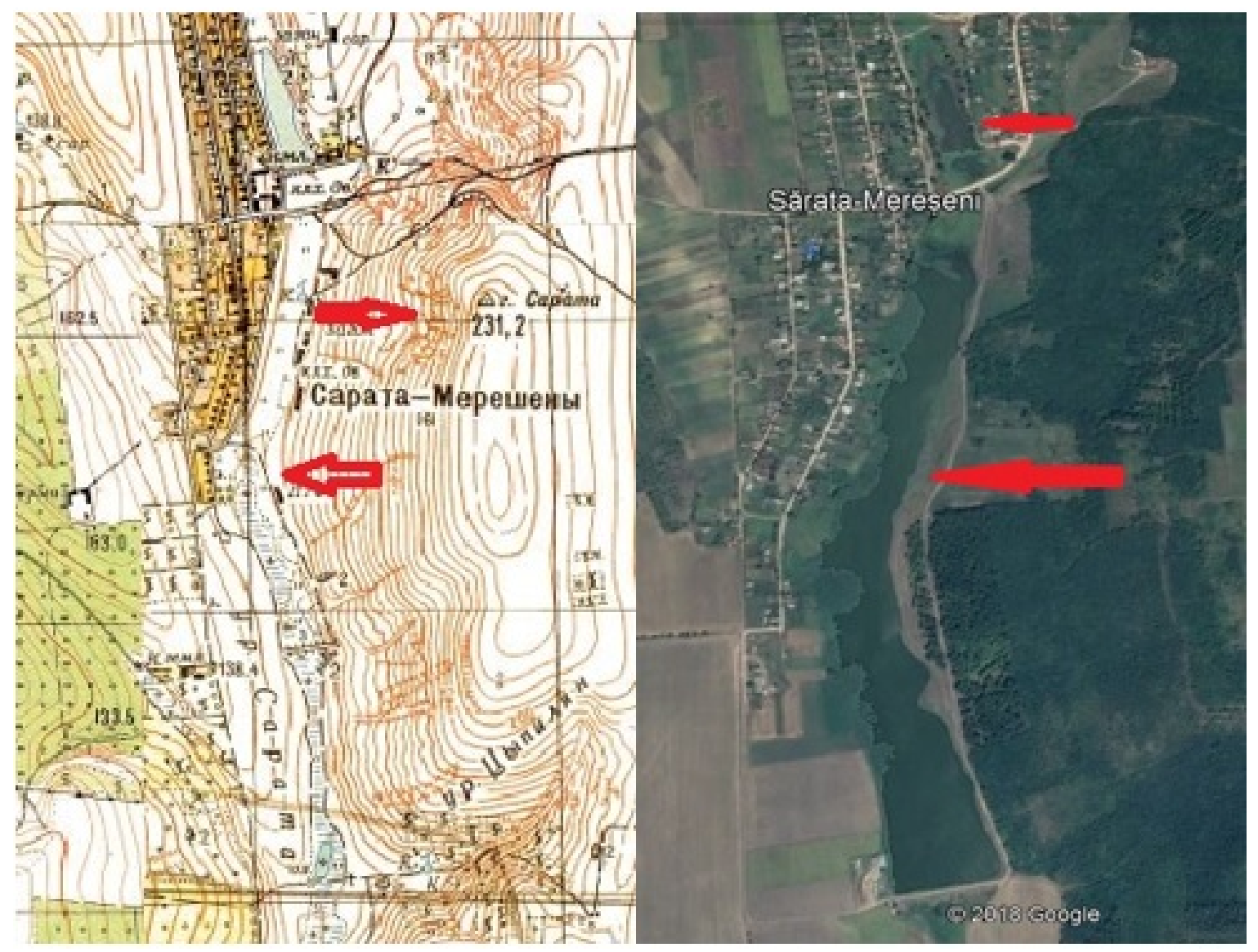

Figure 4. Extension of the lake Sarata Mereseni (after 1970); forest plantations were missing (1957-1970).

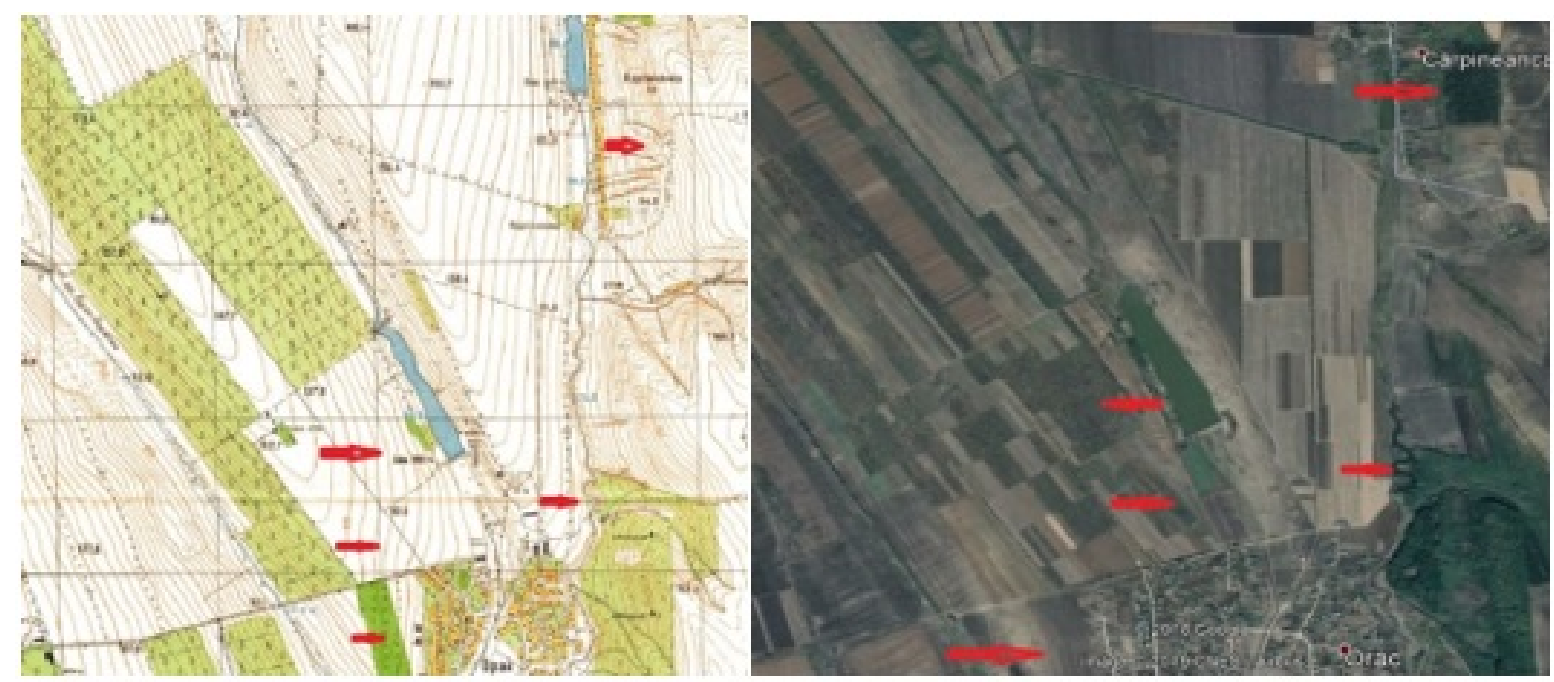

Figure 5. Plantations of vineyards and forests (Carpineanca) appeared after 1970; new lake built in the NE of village Orac; fragmentation of territory in a lot of plots - the 1991s land reforms. 


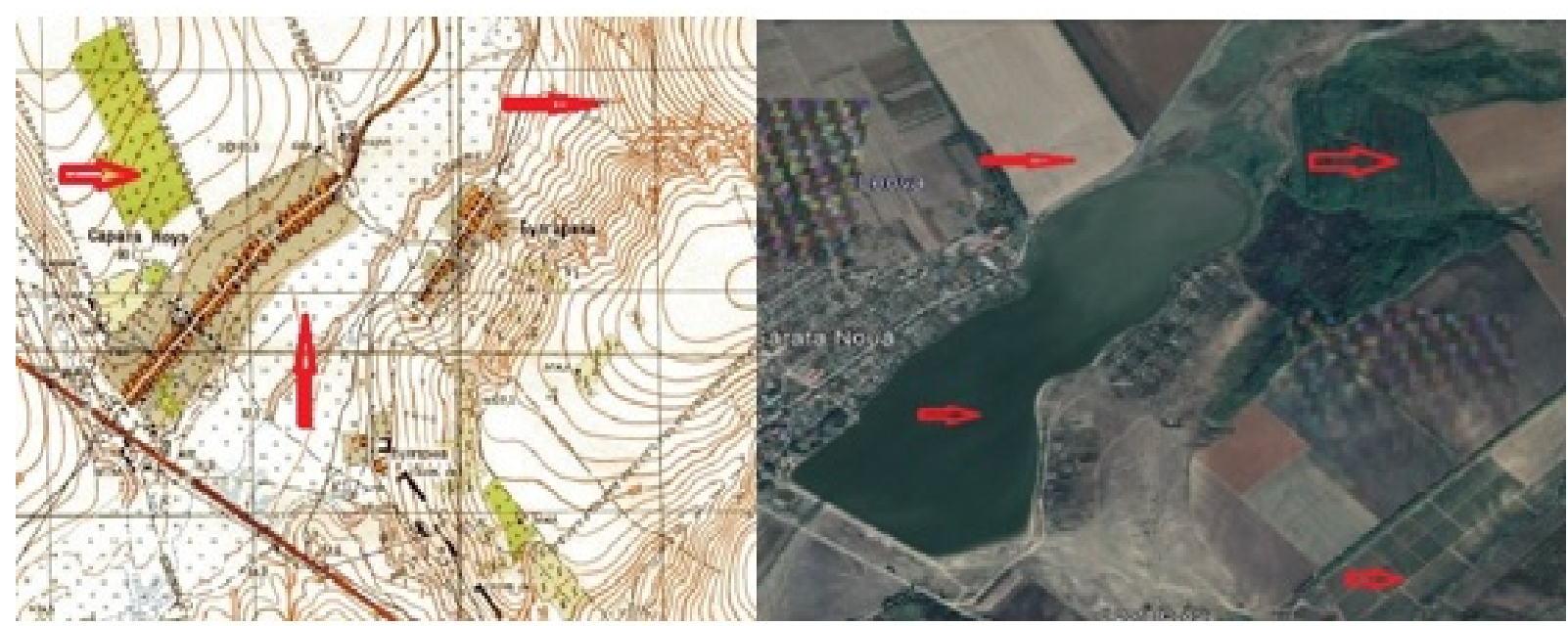

Figure 6. New surfaces of vineyards cultivated in the west of Sarata Noua ; Orchard plantations transformed into arable NV; The emergence of the largest lake Sarata Noua.

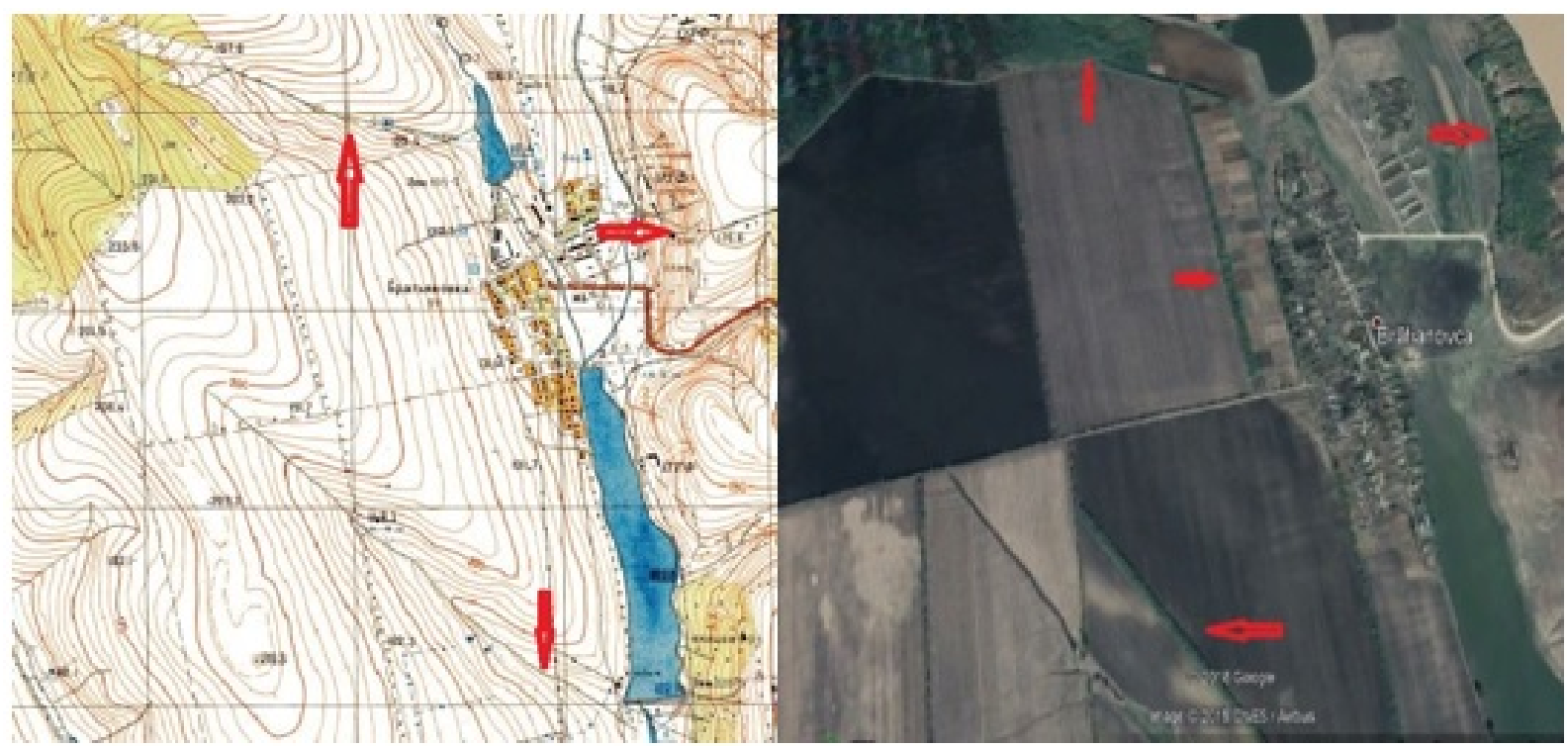

Figure 7. Creation of new forest curtains, planting forests after 1970-2018 (aerophotos 2018); surface erosion.

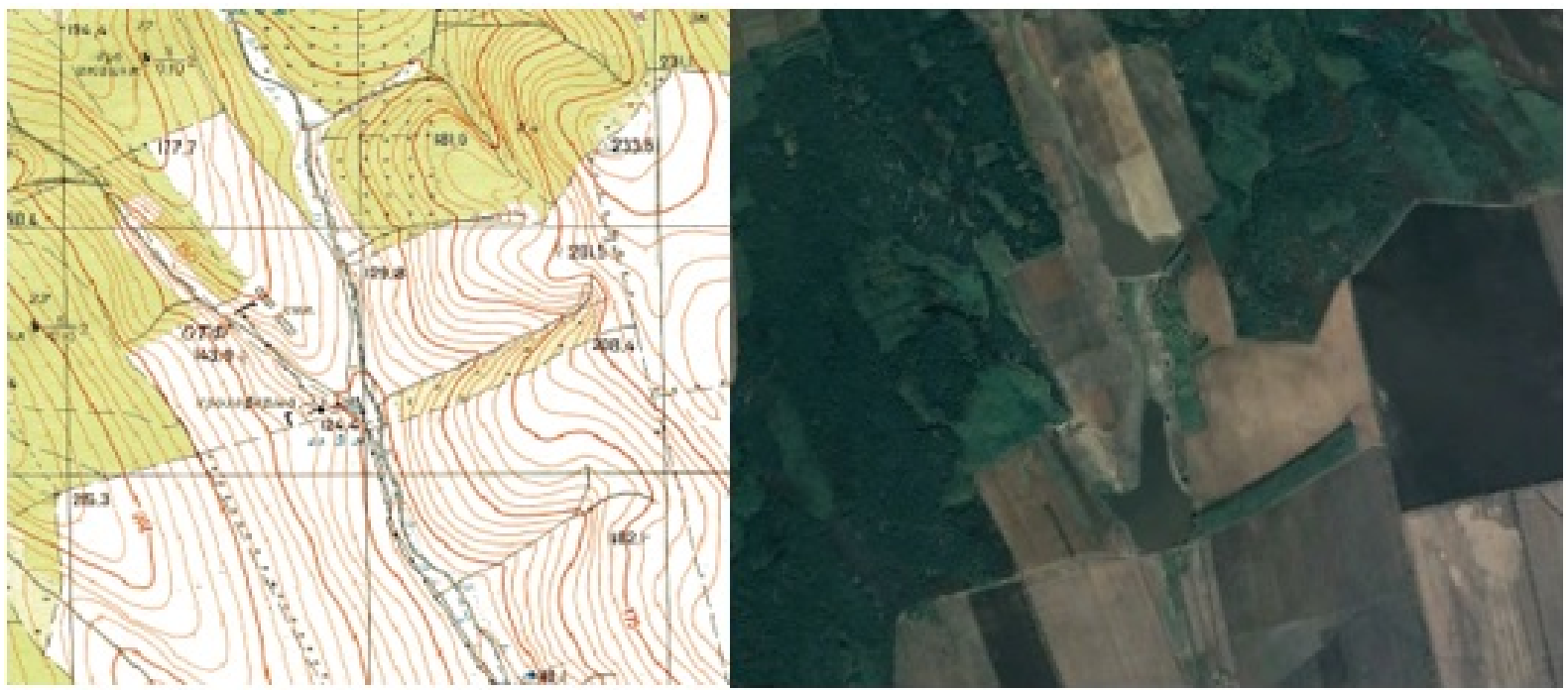

Figure 8. North of Valea Florii - absence of lakes in 1957 and now are presented. 


\section{RESULTS AND DISCUSSION}

Following this study, for the period 1957-1980 we found $71 \%$ for arable area, $10.32 \%$ for forestlands and about $7 \%$ for areas with vineyards, followed by pastures - 4\%. According to the data, aerophotos and observing the others on the field observations it was concluded that the areas have increased for agricultural uses such as vineyards, orchards, villages, forest plantations, lakes (tab.1). It is also important that the important changes in the territory were signaled after the 1991 Land Reform where surfaces with buildings, vineyards and orchards were transformed into arable, accentuating the surface erosion and the silting of the lakes (e.g Sarata Galbena) (tab.fig).

It is observed that for most lakes the area has expanded (due to extension works, regularization) and others have become silted. Thus, a total of about 495.22 ha is estimated for the surface areas of accumulation lakes from the current period (aerophotos 2018) with $41.29 \%$ higher than in the Soviet period (1957-1989) about 204.51 ha .

The intensity of the erosion processes determined the silting of some lakes as a result of the anthropic intervention.Thus, new lakes missing from the topographic maps from 1957-1970 were identified on aerophotograms. Therefore, as a result of the analysis of the 37 lakes of the area and were found:

- 1 lake kept relative the same surface: Cărpineanca N (5.23 ha -5.25 ha).

- 5 lakes have greatly reduced their area, in the case of some, even in half: Lake SarataMereșeni, from 2.82 ha to 1 ha, Lake Brătianovca de S, from 35.65 to 34.3 ha, Câzlari NE from 6.12 ha to 2.48 ha, Victoria SE 1 from 7.54 ha to 4 ha, Cazangic NE from 1.81 to 1.1 ha.

- 20 lakes were built later, after 1970, thus being part of the great project of anti-erosion planning, at the level of the whole Republic of Moldova: Sărata-Mereșeni S (11 ha), Mereșeni S1 (912.8 ha), Mereșeni SE (1.94 ha ), Valea Florii (8.78 ha), Sarata Galbena NE1 (4.3 ha), Sarata Galbena NE 2 (4.95 ha), Carpineanca S (1.25 ha), Orac- Balănei (1.25ha), Ciadâr N (2.35 ha), Colibabovca NV ( 4 ha), Colibabovca S (3ha), Sarateni NV (11.5 ha), Caracui (5.49 ha), Cazlari E (1.51 ha), Victoria SE 2 (4.66 ha), Victoria SV (3.81 ha), Sărățica Veche (12.5 ha) ), Sărățica Nouă (4.57 ha), Troian NE (58 ha), Sărata-Nouă (130 ha).

- 3 lakes built between 1957-1970 which no longer exists, being actually silted due to the intense sedimentation processes: Mereșeni 1, Sărata Galbenă, Cîmpul Drept.

- 8 lakes benefited from cleaning, decolmatization, extension works, as antierosion measures, so that their surfaces increased - Mereșeni S2 from 5.26 ha to 6.37 ha, Brătianovca de N (Valea Siliști) from 6.12 ha to 7.68 ha, Brătianovca - from N from 4.52 ha to $13.9 \mathrm{ha}$, Orac - from $9,755 \mathrm{ha}$ to $12.5 \mathrm{ha}$, Colibabovca SV from 4.06ha to 6.58ha, Sărăteni NE from 14.03 ha to 20.8 ha, Cneazevca from 44.89 ha 77.6 ha, Filipeni S of 20.74 ha 25 ha (Tab.2).

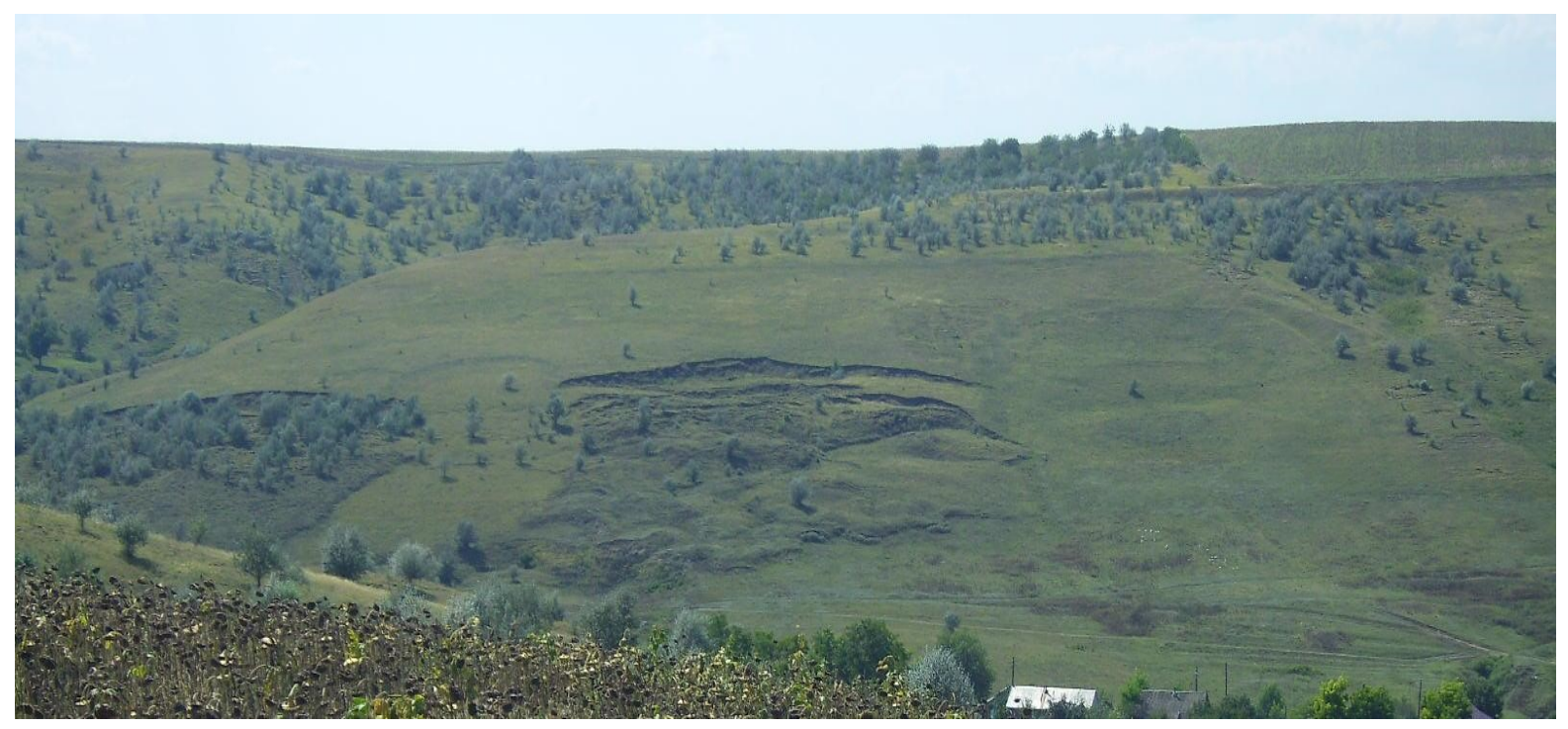

Figure 9. Landslides stabilized in the east of Upper Sarata Catchment, cuesta front, ( august 2019). 
Table 1. Land cover in Sarata catchment (2019)

\begin{tabular}{|l|c|c|}
\hline Land use categorie & Area (ha) & \% of total \\
\hline Arable lanf & 50222.22 & 71.51 \\
\hline Pastures and meadows & 2838.59 & 4.04 \\
\hline Orchards & 1266.93 & 1.8 \\
\hline Orchards (walnut) & 129.29 & 0.18 \\
\hline Vineyards & 5269.63 & 7.5 \\
\hline Lakes & 234.07 & 0.33 \\
\hline Forestlands (acacia) & 2044.19 & 2.91 \\
\hline Forestlands (acacia-maple) & 425.27 & 0.6 \\
\hline Forestlands (oak-maple) & 582.51 & 0.82 \\
\hline Forestlands (oak-acacia) & 1356.17 & 1.93 \\
\hline Forestlands (oak) & 2857.64 & 4.06 \\
\hline Roads & 255.67 & 0.36 \\
\hline Constructions & 1837.91 & 2.61 \\
\hline Marshes & 483.15 & 0.68 \\
\hline Total area & $\mathbf{7 0 2 2 8 . 2 7}$ & 100 \\
\hline
\end{tabular}

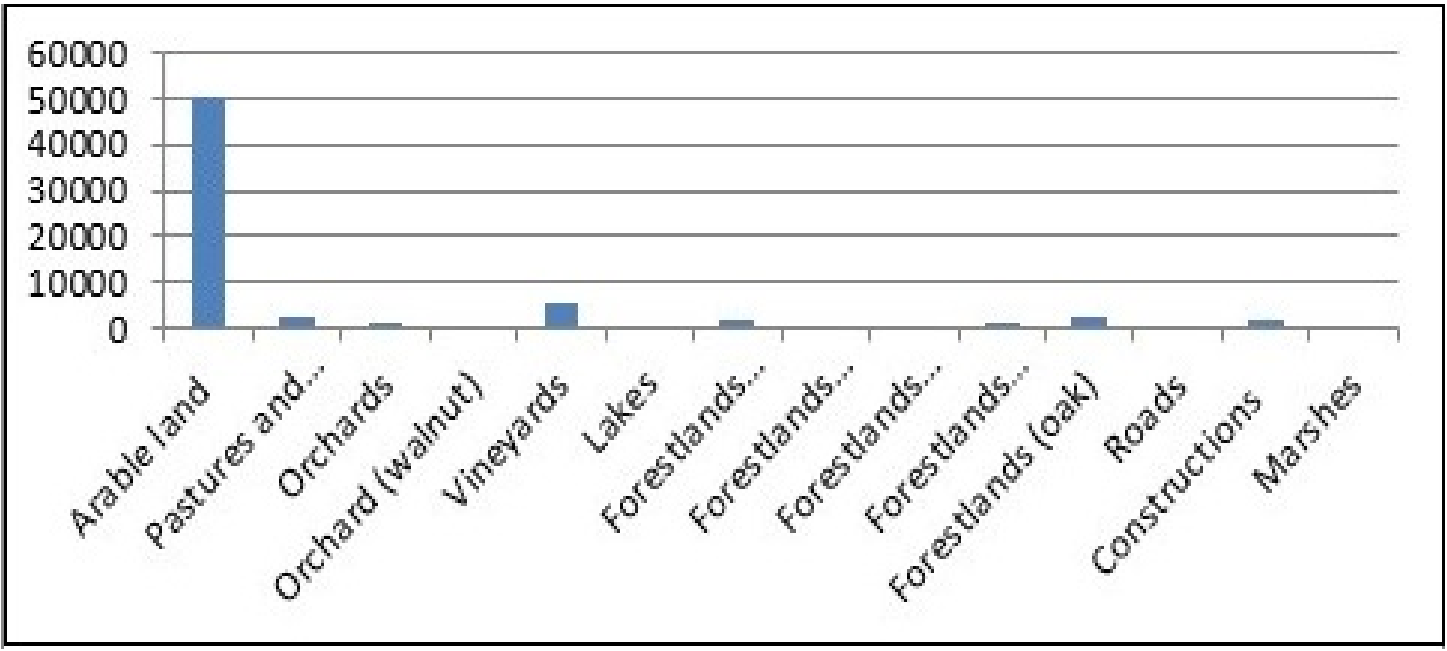

Figure 10. Land cover in Sarata catchment in 2018 (in ha).

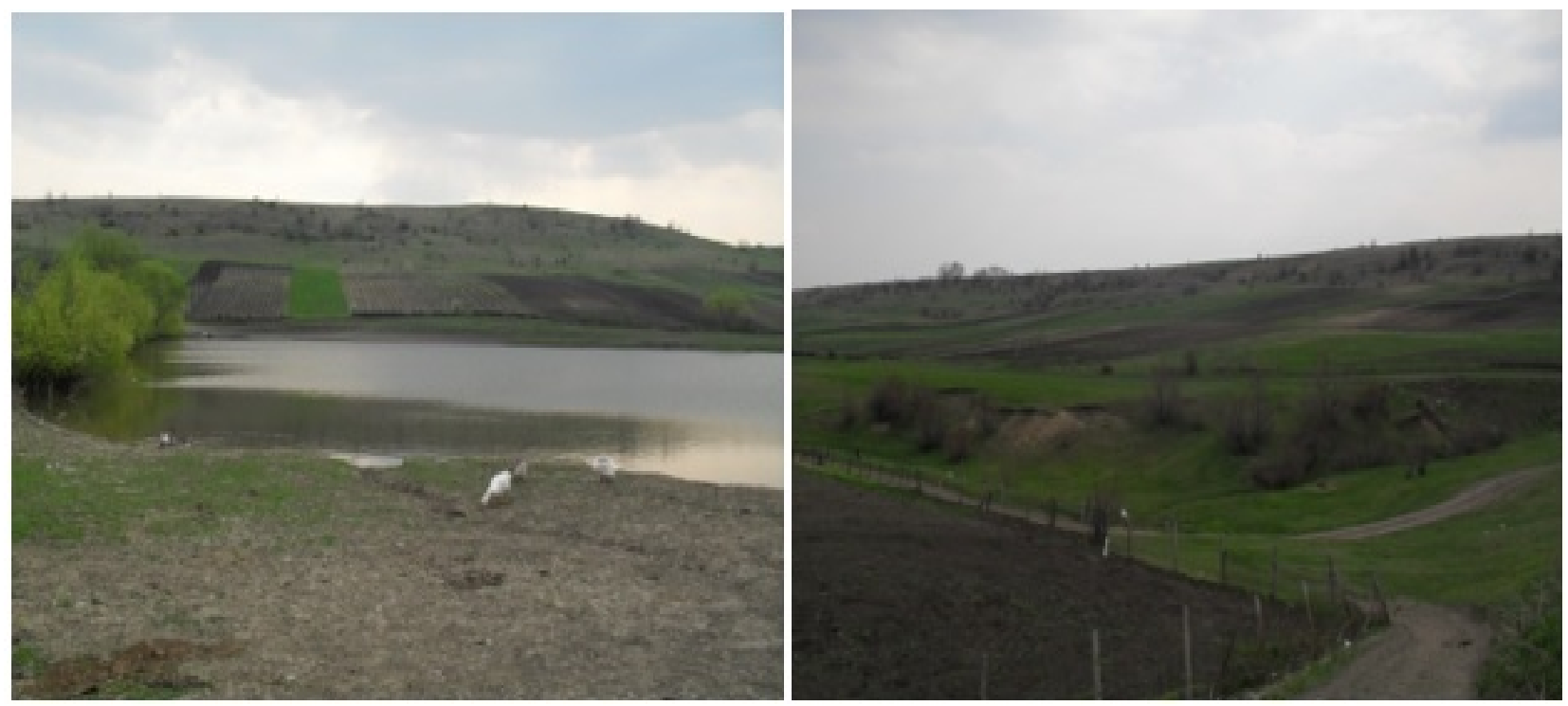

Figure 11. Areolar erosion and in depth, combined with landslides; stabilized sliding ledges (mounds) (middle basin - affluent Ciadar. 
Table 2. . Distribution of lakes in the basin within the Sarata catchment

\begin{tabular}{|c|c|c|c|}
\hline Nr. & Lakes & $\begin{array}{c}\text { topographic map 1957-1990 } \\
\text { (ha) }\end{array}$ & $\begin{array}{l}\text { aerophotos-2018 } \\
\text { (ha) }\end{array}$ \\
\hline 1 & Sărat9-Nerenteni & 2.82 & 1 \\
\hline 2 & Shrata-MerereniS & 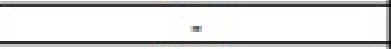 & 11 \\
\hline 3 & Mereseni & 0.27 & - \\
\hline 4 & MeregeniS 1 & - & 12.8 \\
\hline 5 & Meresteni S 2 & 5,26 & 6.37 \\
\hline 6 & Merereni SE & - & 1.94 \\
\hline 7 & Brätianouca de N (Valeg Siligti) & 6.12 & 7.68 \\
\hline 8 & Brătianexca de N & 4.52 & 13.9 \\
\hline 9 & Britimewea des & 35.65 & 34.3 \\
\hline 10 & Valea Flonii & - & 8.78 \\
\hline 11 & Sărata Galberă & 19.78 & silted \\
\hline 12 & Sărata Galbenā NE 1 & - & 4.3 \\
\hline 13 & Sărata Galbenă NE 2 & - & 4.95 \\
\hline 14 & Cinginearsa $\mathrm{N}$ & 5.23 & 5.25 \\
\hline 15 & Cămineanca S & - & 1.25 \\
\hline 16 & Oras & 9.755 & 12.5 \\
\hline 17 & Orac Balănei & - & 1.25 \\
\hline 18 & Ciadâr N & - & 2.35 \\
\hline 19 & Colibgbowca SV & 4.06 & 6.58 \\
\hline 20 & Colibaboxca NV & - & 4 \\
\hline 21 & Colibaboxca S & $=$ & 3 \\
\hline 22 & Säräteni NV & - & 11.5 \\
\hline 23 & Săxăteoj NE & 14.03 & 20.8 \\
\hline 24 & Caracui & - & 5.49 \\
\hline 25 & Cueazerca & 44.89 & 77.6 \\
\hline 26 & CazlaniNE & 6.12 & 2.48 \\
\hline 27 & CâzlariE & - & 1.51 \\
\hline 28 & Victoria SE 1 & 7.54 & 4 \\
\hline 29 & Victoria SE 2 & - & 4.66 \\
\hline 30 & Victoria SV & - & 3.81 \\
\hline 31 & Sárătica Veche & - & 12.5 \\
\hline 32 & Sărătica Nouğ & - & 4.57 \\
\hline 33 & Cinpul Drept & 16.19 & silted \\
\hline 34 & Troian NE & - & 58 \\
\hline 35 & CazangicNE & 1.81 & 1.1 \\
\hline 36 & Särats-Nouã & - & 130 \\
\hline 37 & EilipeniS & 20.74 & 25 \\
\hline & Total area & 204.51 & 495.22 \\
\hline
\end{tabular}

Thus the degradation of the lands is in a continuous increase, although the anti-erosion Programs and the conservation practices (from the Soviet period) are still partially preserved in the territory. It is very important and absolutely necessary to continue to implementation projects of erosion management and land conservation practices for reducing soil erosion and lake sedimentation. In conclusion, soil erosion in the Sarata catchment is the most important degradation process and is directly related to the increasingly anthropic intervention, especially due to land reforms.

\section{ACKNOWLEDGEMENTS}

This work was co-funded by the European Social Fund, through Operational Programme Human Capital 2014-2020, project number POCU/380/6/13/123623, project title „PhD Students and Postdoctoral Researchers Prepared for the Labour Market!".

\section{REFERENCES}

[1] Ioniţă, I., Niacşu, L., (2010), Land degradation and soil conservation within the Pereschivul Mic catchment Tutova Rolling Hills, Lucrări ştiinţifice - vol. 53, seria Agronomie, Ed. „Ion Ionescu de la Brad” Iaşi , Romania.

[2] Niacşu, L., 2017. Land degradation and soil conservation within the Moldavian Plateau. Habilitation Thesis, Univ. „Al. I. Cuza”, Iaşi, 102 pp, Romania. 
[3] Ioniţă I., (2000a) Geomorfologie aplicată - Procese de degradare a regiunilor deluroase, Editura Univ.”Al. I. Cuza", 249 pp, Iaşi, Romania.

[4] ICPA "Nicolaie Dimo", 2004 "Eroziunea solului”, Republica Moldova.

[5] Ioniţă, I., Rădoane, Maria, Mircea, S., (2006), “1.13 Romania”, In "Soil Erosion in Europe”, Editors JohnBoardman and Jean Poesen, Publisher John Wiley, Chichester, England.alea Bârladului, Analele ştiinţifice ale Universităţii „Al. I. Cuza, tom XII, Iaşi, Romania.

[6] Rădoane, Maria, Ichim, I., Rădoane, N., (1995), Gully distribution and development in Moldavia, Romania, Catena 24: 127-146, Romania.

[7] Ioniţă, I., (2000b), Formarea şi evoluţia ravenelor din bazinul Bârladului, Ed. „Corson” Iaşi, Romania.

[8] Pujină, D., (1997), Cercetări asupra unor procese de alunecare de pe terenurile agricole din Podişul Bârladului şi contribuţii privind tehnica de amenajare a acestora, Teză de doctorat, Univ. „Gh. Asachi”, Iaşi, Romania.

[9] Niacsu L., 2012. Pereschiv catchment (Tutova Rolling Hills). Geomorphological and pedogeographical study with special regard on land use, Ph.D. thesis, Alexandru Ioan Cuza University of Iasi, pp 308 ,Romania.

[10] Niacşu L., Stoian L., Topsa G. 2012. Land degradation and soil conservation within the Simila catchment - Tutova rolling hills, Present environment and sustainable development, 6 (2), 465-475, Romania.

[11] Motoc, M. 1983. Ritmul mediu de degradare erozionala a solului in R. S. Romania. Buletinul Informativ al A.S.A.S., 13, Bucuresti, pp. 47-65, Romani 